\title{
Sandal Ağacı (Arbutus andrachne) Yapraklarının Potansiyel Besleme Değerinin Belirlenmesi
}

\author{
Adile TATLIYER ${ }^{\mathscr{P}(D)}$, Adem KAMALAK $^{2}$ (D), Durmuş ÖZTÜRK ${ }^{3}$ D \\ 1,2,3Kahramanmaraş Sütçü İmam Üniversitesi, Ziraat Fakültesi, Zootekni Bölümü, Kahramanmaraş \\ ${ }^{1}$ https://orcid.org/0000-0002-4239-7072, ${ }^{2} \mathrm{https} / / /$ orcid.org/0000-0003-0967-4821, ${ }^{3}$ https://orcid.org/0000-0002-7706-1798 \\ $\square$ : atatliyer@ksu.edu.tr
}

\section{ÖZET}

$\mathrm{Bu}$ çalışmanın amacı, hasat zamanının sandal ağacı yapraklarının kimyasal kompozisyonuna, metabolik enerji değerine (ME) ve in vitro kuru madde sindirim derecesine (IVKMSD) olan etkisini belirlemektir. Hasat zamanı sandal ağacı yaprağının kompozisyonunu, IVKMSD ve ME içeriğini önemli derecede etkilemiştir. Yaprakların IVKMSD \%28.56 ile \% 67.73 arasında değişmiş olup en yüksek IVKMSD’i Ocak ve Nisan aylarında en düşük IVKMSD'ne ise Ekim ayında hasat edilen yapraklarda bulunmuştur. Yaprakların ME içeriği \% 3.11 ile \%9.02 MJ/kg arasında değişmiş olup en yüksek ME Ocak ayında ve en düşük ME değeri ise Ekim ayında hasat edilen yapraklarda bulunmuştur. Sonuç olarak sandal ağacı yaprağının kimyasal kompozisyonu, IVKMSD ve ME içeriği hasat zamanına bağlı olarak değişmiştir. Dört farklı dönemde hasat edilen sandal ağacının yapraklarının protein ve mineral içerikleri düşük olduğundan koyun ve keçilerin ihtiyacını karşılamak için sandal ağacının yaprakları protein $\mathrm{P}, \mathrm{Cu}$ ve $\mathrm{Mn}$ kaynakları yeme eklenmelidir.

\section{Araştırma Makalesi}

Makale Tarihçesi

Geliş Tarihi : 05.11.2018

Kabul Tarihi : 24.12.2018

Anahtar Kelimeler

Sandal ağacı

Besleme değeri

Hasat zamanı

Kimyasal kompozisyon

\section{Determination of Potential Nutritive Value of Leaves of Arbutus andrachne}

\section{ABSTRACT}

The objective of this study was to determine the effect of harvest stage on the chemical composition, metabolisable energy and dry matter digestibility of $A$. andrachne leaves. Harvesting stage had a significant effect on the chemical composition, metabolisable energy and dry matter digestibility of leaves of $A$. andrachne. The IVDMD of the leaves of $A$. andrachne ranged from 28.56 to $67.73 \%$. The highest IVDMD was obtained in January and April whereas the lowest IVDMD was obtained in October. The ME contents of the leaves of $A$. andrachne ranged from 3.11 to $9.02 \mathrm{MJ} / \mathrm{kg}$ DM. The highest IVDMD was obtained in January whereas the lowest IVDMD content was obtained in October. As conclusion the chemical composition, IVDMD and ME content of the leaves ranged with harvesting time. Leaves of $A$. andrachne should be supplemented with protein, $\mathrm{P}, \mathrm{Cu}$ and $\mathrm{Mn}$ minerals sources to meet the requirement of sheep and goat since the leaves of $A$. andrachne harvested in four periods were low in crude protein and minerals.

\section{Research Article}

\section{Article History}

Received : 05.11.2018

Accepted : 24.12.2018
Keywords
Arbutus adrachne,
Nutritive value,
Harvest stage,
Chemical composition

To Cite : Tatliyer A, Kamalak A, Öztürk D. Sandal Ağacı (Arbutus andrachne) Yapraklarının Potansiyel Besleme Değerinin Belirlenmesi. KSÜ Tarım ve Doğa Derg 22(2): 315-321. DOI: 10.18016.ksutarimdoga.vi.478849

\section{GİRIŞ}

Dünyanın pek çok yerinde ağaçlar ve çalılar hem yem kaynağı, hem yakacak hem de erozyon kontrolü gibi çok amaçlı kaynaklar olarak kullanılmaktadır (Smith, 1992). Özellikle yem kaynaklarının kısıtlı olduğu yerlerde ağaçların dal ve yapraklarının hayvan yemi olarak kullanılması büyük önem kazanmaktadır. Keçi, koyun ve geyik gibi ruminant hayvanlar için ağaç dal ve yaprakları diyetin önemli bir kısmını oluşturabilmektedir (Kamalak ve ark., 2005). Bununla birlikte, bazıları geleneksel olarak uzun yıllardır kullanılan bu ağaç ve çalıların beslenme değerli hakkında da pek az bir bilgi söz konusudur. Daha önce üzerinde araştırma yapılmamış dal ve yapraklarının beslenme değerleri ortaya konulması hayvan besleme açısından çok yararlı olacaktır (Ammar ve ark. 2005). Ağaç ve çalı yapraklarında bulunan tanen ve diğer fenolik bileşikler önemli besinsel öğelerin hayvanların 
beslenmesinde kullanımını engellemektedir (Tolera ve ark. 1997). Yapraklarda bulunan yüksek tanen, besin maddelerinin kullanımını ve yem yeme isteğini, besinin sindirilebilirliğini düşürmekte ve vücutta $N$ depolanmasinı kisitlamaktadır (Kumar ve Vaithiyanathan 1990, Silanikove ve ark.,1996; 2001).

Alternatif yem kaynağı olarak değerlendirilebilen ağaç yaprakları sulu kaba yemler sınıfına girmektedir. Keçi ve koyun başta olmak üzere hayvanlar, ağaç yapraklarını severek yemektedirler. Bu nedenle tarım işletmelerindeki meyve, süs ve orman ağaçlarının yaprakları bu amaç için değerlendirilmektedir. Türkiye'nin birçok yöresinde başta akasya olmak üzere, meşe, sandal ve zeytin ağaçlarının yaprakları zaman zaman budanıp yem olarak kullanılmaktadır. Özellikle her dem yeşil olan zeytin ve sandal ağacı gibi ağaç yaprakları keçi ve koyun gibi küçükbaş ruminant hayvanlar için $\mathrm{k} ı s ̧$ beslenmesinde yetiştiriciler için değerli bir kaba yem kaynağıdır. Bu bitkilerden sandal ağacı (A. andrachne L.) özellikle Ceyhan Nehri vadisi gibi Akdeniz iklimine sahip olan yerlerde doğal olarak yetişmektedir.

$\mathrm{Bu}$ araştırma; Kahramanmaraş ilinde çiftçiler tarafından yoğun olarak keçi ve koyunların beslenmesinde kullanılan sandal ağacı ( $A$. andrachne L.) yapraklarının, ham ve sindirilebilir besin maddelerinin tespit edilmesi, metabolik enerji içeriği ve içerisindeki tanen miktarının saptanması, bu değerlerin mevsimsel olarak değişiminin ortaya konulması ve yemin hasat zamanına göre potansiyel besleme değerinin belirlenmesi amaçlanmıştır.

\section{MATERYAL ve METOD}

\section{Yaprak Materyali}

Sandal ağacı (A. andrachne L.) yaprakları Kahramanmaraş - Andırın kara yolunun 35. kilometresinde bulunan Ceyhan Nehri-Körsulu Vadisi bölgesinden elle toplanmıştır. Bölgenin rakımı yaklaşık 600-800 m'dir. Sandal ağacı yaprakları 2011 yılının Ocak, Nisan, Temmuz ve Ekim aylarında toplanmıştır.

\section{Kimyasal Analizler}

Toplanan sandal ağacı yaprakları gölgede kurutulmuş olup kuru yaprak örneklerinin kuru madde içerikleri $105^{\circ} \mathrm{C}$ sicaklıktaki etüvde 24 saat süreyle kurutularak tespit edilmiştir. Kuru yem örnekleri $1 \mathrm{~mm}$ elekten geçecek şekilde öğütülmüş naylon torbalar içerisinde buzdolabında sonraki analizler için saklanmıştır. Sandal ağacı yaprağının kuru madde, ham kül, ham protein, ham yağ içerikleri AOAC (1990)'ın bildirdiği metotlara göre yapılmıştır. Sandal ağacı yaprağının asit deterjan fiber (ADF) ve nötral deterjan fiber (NDF) içeriği Van Soest (1991)'in bildirdiği yöntemlerle yapılmıştır. Sandal ağacının besin madde içerikleri kuru madde bazında verilmiştir.
Sandal ağacı yapraklarının in vitro sindirim derecesi İki Aşamalı Sindirim Tekniği (Tilly ve Terry, 1963) ile belirlenmiştir. Yaklaşık 0.5 gram yem örnekleri tampon solüsyonla karıştırılmış koyunlardan elde edilen rumen sivisiyla $38{ }^{\circ} \mathrm{C}^{\prime}$ de 24 saatlik fermentasyona tabi tutulmuştur. Rumen sivisı Kahramanmaraş hayvan pazarında kesilen koyunlardan kesimi takiben hemen almarak termosa konulmuş, mikroorganizma faaliyetinin devamı için hızla laboratuvara getirilmiştir. İkinci aşamada yem örnekleri pepsin içeren solüsyonla $38{ }^{\circ} \mathrm{C}$ 'de 24 saatlik bir inkübasyona daha tabi tutularak, inkübasyon sonunda 4 Nolu Whatman kâğıdı kullanılarak süzme işi yapılmıştır. Kuru maddenin IVKMSD (\%) aşağıdaki formül kullanılarak hesaplanmıştır.

\section{IVKMSD $=\frac{\text { Giren } \text { kuru madde }- \text { kalan } \text { kuru madde }}{\text { Giren } \text { kuru madde }} \times 100$}

Sandal ağacının ME içeriği MAFF (1984)'ın belirttiği formül kullanılarak hesaplanmıştır.

ME: $13.5-0.15$ ADF\% + 0.14HP\% - $0.15 \mathrm{Kül} \%$, MAFF, 1984)

Sandal ağacının $\mathrm{Ca}, \mathrm{Mg}, \mathrm{K}, \mathrm{Zn}, \mathrm{Fe}, \mathrm{Mn}$ ve $\mathrm{Cu}$ içerikleri Jones ve Case (1990) bildirdiği yönteme göre yapılmıştır. Sandal ağacının P içeriği ise Vanadomolibdofosforik asit yöntemiyle belirlenmiştir (Kuo, 1996).

\section{İstatistiksel Analizler}

Sandal ağacının kimyasal kompozisyonu, kuru madde sindirim derecesi ve metabolik enerji değerine hasat zamanının etkisini belirlemek için elde edilen veriler tek yönlü varyans analizine (ANOVA) tabi tutulmuş olup ortalamalar arasındaki farklar Tukey çoklu karşılaştırma testiyle belirlenmiştir. Ortalamalar arasındaki farklılıklara $\mathrm{p}<0.05$ düzeyinde bakılmıştır.

\section{BULGULAR ve TARTIŞMA}

Sandal ağacının kimyasal kompozisyonu, İKMSD ve ME değerine hasat zamanının etkisi Çizelge 1'de verilmiştir. Hasat zamanı sandal ağacı yaprağının kimyasal kompozisyonunu, İKMSD ve ME değerini önemli derecede etkilemiştir. Sandal ağacının kimyasal kompozisyonu, İKMSD ve ME değeri hasat zamanına bağlı olarak değişim göstermiştir.

Sandal ağacının HP içeriği \% 4.66 ile \% 7.34 arasında değişmiş olup en yüksek HP içeriğine Ocak ayında elde edilen yapraklar sahip olmuştur. Nisan ve Temmuz aylarında elde edilen sandal ağacı yapraklarının ham protein içeriği Kamalak ve ark. (2010) bildirdiği değerlerle benzerlik göstermesine rağmen Ocak ve Ekim ayında elde edilen yaprakların ham protein içeriği Kamalak ve ark., (2010)'nın genç ve yaşlı 
yapraklar için bildirdiği $\quad \% \quad 3.46$ ile $\quad \% \quad 4.90$ değerlerinden biraz farklı bulunmuştur. Diğer taraftan çalışmada sandal ağacı yapraklarından elde edilen ham protein değerleri, Kamalak ve ark. (2004a) ve Karabulut ve ark. (2006)'nın yaptıkları çalışmaya göre genel olarak daha düşük bulunurken Ocak ayı için benzerlik göstermiştir. Kamalak ve ark. (2004a) ve Karabulut ve ark. (2006) yaptıkları çalışmada sandal ağacı (A. andrachne L.) yapraklarında HP \% 7.3 olarak bulunmuştur.

Herdem yeşil bitkiler kışa girmeden önce yaşlanan yapraklarını dökmektedir. Yaşlı yapraklarındaki proteinler daha genç yapraklara taşınmaktadır (Yamamura 1986; Minoletti ve Boerner 1994). Proteinlerin yaşlı yapraklarından genç yapraklara translokasyonunun kışın elde edilen yaprakların protein içeriğinden daha yüksek olmasına neden olduğu düşünülmektedir.

Genel olarak \% 8'den az ham protein içeren yemler, rumen mikroorganizmalarının normal faaliyetlerini sürdürmeleri için yeterli olan amonyağı karşılayamaz (Norton, 2003). Bundan dolayı alternatif yem kaynağı olarak kullanılan sandal ağacı yapraklarının ham protein değerleri incelendiğinde besleme amacı ile sadece sandal ağacı yaprağ rumen mikroorganizmalarının faaliyeti için bu yem materyali tek başına yeterli olmayabilir. Yetiştiriciler tarafından kullanıldığında mutlaka yeme bir protein kaynağı ilavesi tavsiye edilmelidir.

Sandal ağacının NDF ve ADF içeriği \% 41.60 ile 65.64 ve 28.90 ile 67.39 arasında değişmiş olup en yüksek $\mathrm{NDF}$ ve ADF içeriklerine Ekim ayından elde edilen yapraklar sahip olmuştur. Sandal ağacı yapraklarının NDF içerikleri; Ocak \% 45.84, Nisan \% 41.60, Temmuz $\% 47.38$ ve Ekim ayı için \% 65.64 olarak bulunmuştur. NDF değeri \% 41.60 ile 65.64 arasında değişmiş olup en yüksek NDF içeriğine Ekim ayında en düşük ise Nisan ayında hasat edilen yapraklarda ulaşılmıştır. Yapraklardaki NDF değeri mevsimden önemli ölçüde etkilenmiştir (Çizelge 1). Ocak, Nisan ve Temmuz aylarında yapraklardaki NDF değerleri bir birine yakın bulunurken Ekim ayında yükselmiştir. Ağaç yapraklarının kompozisyonu mevsime bağlı olarak meydana gelen translokasyondan (besin maddelerin transferi) dolayı değişim göstermektedir. Daha öncede belirtildiği gibi yaşlanma döneminde meydana gelen translokasyon yaprakların başta protein içeriği olmak üzere diğer unsurları değiştirmektedir. Yaprakların hücre duvarını oluşturan unsurların oranındaki mevsimsel değişimin translokasyon ile ilişkili olduğu düşünülmektedir. Bu çalışmada Ocak, Nisan ve Temmuz aylarında hasat edilen yaprakların NDF içeriği Kamalak ve ark. (2010) bildirdiği değerlerle uyum içerisinde olmasına rağmen, Ekim ayında elde edilen yaprakların NDF içeriği Kamalak ve ark. (2010)'nın bildirdiği değerden yüksek bulunmuştur. Kamalak ve ark. (2010) genç ve yaşlı yapraklar için NDF içeriğinin \% 33.75 ile 35.58 arasında değiştiğini bildirmiştir. Farklı dönemlerde hasat edilen sandal ağacının ADF içeriği \% 28.90 ile \% 67.39 arasında değişmiş olup en yüksek ADF içeriğine Ekim ayında en düşük ise Nisan ayında hasat edilen yapraklarda ulaşılmıştır. ADF içerikleri; Ocak \% 34.92 , Nisan \% 28.90, Temmuz \% 39.26 ve Ekim ayı için \% 67.39 olarak bulunmuştur (Çizelge 1).

Çizelge 1. Farklı dönemlerde hasat edilen sandal ağacı yapraklarının kuru madde (\%), besin maddeleri içeriği (\%) ve İVKMSD (\%) ile ME (MJ/kg) değerleri

\begin{tabular}{|c|c|c|c|c|c|c|}
\hline & \multicolumn{4}{|c|}{ Hasat Zamanı } & & \\
\hline Parametreler & Ocak & Nisan & Temmuz & Ekim & SHO & ÖS \\
\hline KM (\%) & $99.55^{\mathrm{a}}$ & $95.13^{b}$ & $97.96^{\mathrm{a}}$ & $98.92^{\mathrm{a}}$ & 0.549 & $* * *$ \\
\hline HK (\%) & $6.70^{\mathrm{ab}}$ & $5.36^{\mathrm{b}}$ & $6.15^{\mathrm{ab}}$ & $7.26^{\mathrm{a}}$ & 0.476 & $* *$ \\
\hline $\mathrm{HP}(\%)$ & $7.34^{\mathrm{a}}$ & $4.66^{\mathrm{b}}$ & $4.63^{\mathrm{b}}$ & $5.80^{\mathrm{ab}}$ & 0.494 & $* * *$ \\
\hline NDF(\%) & $45.84^{b}$ & $41.60^{\mathrm{c}}$ & $47.38^{\mathrm{b}}$ & $65.64^{\mathrm{a}}$ & 0.728 & $* * *$ \\
\hline $\mathrm{ADF}(\%)$ & $34.92^{\mathrm{b}}$ & $28.90^{c}$ & $39.26^{\mathrm{b}}$ & $67.39^{a}$ & 1.404 & $* * *$ \\
\hline HY(\%) & $4.21^{\mathrm{a}}$ & $2.82^{\mathrm{b}}$ & $1.30^{\mathrm{c}}$ & $1.16^{\mathrm{c}}$ & 0.339 & $* * *$ \\
\hline $\mathrm{KT}(\%)$ & $4.90^{c}$ & $5.28^{\mathrm{c}}$ & $8.35^{c}$ & $11.13^{\mathrm{a}}$ & 0.718 & $* * *$ \\
\hline İVKMSD (\%) & $50.54^{b}$ & $67.73^{\mathrm{a}}$ & $30.25^{c}$ & $28.56^{c}$ & 6.22 & $* * *$ \\
\hline ME MJ/kg KM & $8.28^{\mathrm{b}}$ & $9.02^{\mathrm{a}}$ & $7.33^{c}$ & $3.11^{\mathrm{d}}$ & 0.188 & $* * *$ \\
\hline
\end{tabular}

abc Aynı üst simgeye sahip ve aynı satırda yer alan ortalamalar arasında fark yoktur (P>0.05), SHO: Standart hata ortalaması, ÖS: Önem seviyesi, KM: Kuru madde, HK: Ham kül, HP: Ham protein, NDF: Nötral deterjan fiber, ADF: asit deterjan fiber, HY: Ham yağ, KT: Kondense tanin, IVKMSD: İn vitro kuru madde sindirim derecesi(\%),

Bu çalışmada Ocak, Nisan ve Temmuz aylarında hasat edilen yaprakların ADF içeriği Kamalak ve ark. (2010)'nın bildirdiği değerlerle uyum içerisinde olmasına rağmen, Ekim ayında elde edilen yaprakların ADF içeriği, NDF değerlerinde olduğu gibi, Kamalak ve ark. (2010)'nın bildirdiği değerden yüksek bulunmuştur. Kamalak ve ark. (2010) genç ve yaşlı yapraklar için ADF içeriğinin \%29.50 ile 30.22 arasında değiştiğini bildirmiştir. $\mathrm{Bu}$ durumun yaprakların alındığı ağaçların bölge ve yaşından kaynaklandığı düşünülebilir. Tanen içermeyen yem örneklerinde NDF içeriği her zaman ADF içeriğinden yüksek olmaktadır. Oysa ki Ekim ayında hasat edilen 
sandal ağacı yapraklarının ADF içeriği NDF içeriğinden yüksek bulunmuştur. Bunun sebebi asidik koşullarda bazen tanen ile hücre duvarı unsurları arasında oluşan bileşikler asit deterjan solüsyonunda çözünmediğinden dolayı $\mathrm{ADF}$ içeriği NDF içeriğinden daha yüksek olmaktadır. Benzer şekilde Getachew ve ark. (2000) yaptığ̣ çalışmada ADF içeriklerinin NDF içeriklerden yüksek olduğu bildirilmiştir.

Sandal ağacının HY içeriği \% 1.16 ile 4.21 arasında değişmiş olup en yüksek HY içeriğine Ocak ve Nisan aylarında elde edilen yapraklar sahip olmuştur. Sandal ağacının KT içeriği \% 4.90 ile \% 11.13 arasında değişmiş olup en yüksek KT içeriğine Ekim ayında elde edilen yapraklar sahip olmuştur.

$\mathrm{Bu}$ çalışmadaki Ocak, Nisan ve Temmuz aylarında hasat edilen yaprakların KT içeriği Kamalak ve ark. (2010) bildirdiği değerlerden düşük olmasına rağmen Ekim ayında elde edilen yaprakların KT içeriği benzerlik göstermiştir. Kamalak ve ark. (2010), genç ve yaşlı sandal ağacı yaprakları için KT içeriğini \%11.63 ile \%14.64 arasında değiştiğini bildirmektedirler. Bilindiği gibi ağaçların yapraklarındaki KT çözünebilirliğini ve seviyesini etkileyen birçok faktör vardır. Yapraklardaki KT miktarı genotipe bağlı olarak değişmektedir (Baldwin ve ark., 1987). Tanen seviyesi büyüme dönemine doğru belirgin biçimde değişiklik göstermektedir (Hagerman, 1988). Ağaç ve çalıların yapraklarındaki KT içeriği yaprak yaşı ve ağacın yaşından dolayı da değişiklik gösterebilir. Degen ve ark. (1997) Acacia saligna ağacında yaşlı yapraklarda genç yapraklara göre toplam tanen miktarını 1.5 kat daha fazla olduğunu bulmuşlardır. Makkar ve ark. (1991), meşe ağaçları üzerinde yaptıkları birçok çalışmada yapraklar olgunlaştıkça KT miktarının arttığını gözlemlemişlerdir. Bununla beraber toplam çözünebilir fenoller bazı türlerde genç yapraklarda daha fazla bulunurken, diğer türlerde genç yapraklarda daha az bulunmuştur.

Sandal ağacının IVKMSD \% 28.56 ile 67.73 arasında değişmiş olup en yüksek İVKMSD değerine Nisan ayında elde edilen yapraklar sahip olmuştur. Yapraklardaki IVKMSD mevsimin ilerlemesi ile yani ilkbahardan sonbahara doğru hızla düşmüştür. Bu da ADF ve NDF"nin artması ile paralellik göstermektedir. Çalışmada Nisan ayında hasat edilen yaprakların IVKMSD'si Karabulut ve ark. (2006), Kamalak ve ark. (2005)'nın bildirdiği değerlerle uyum içerisindedir. Ekim ayında elde edilen yaprakların IVKMSD içerikleri ise Karabulut ve ark. (2006) ve Kamalak ve ark. (2005) bildirdiği değerden oldukça düşük bulunmuştur. Yukarıda da değinildiği gibi, Ekim ayında hasat edilen yapraklarının İVKMSD'nin düşük olmasının sebebi, NDF, ADF ve kül içeriğinin bu dönemde oldukça yüksek olmasından kaynaklandığı düşünülmektedir.

Sandal ağacında ME 3.11 ile 9.02 MJ arasında değişmiş olup en yüksek ME değerine Nisan ayında elde edilen yapraklar sahip olmuştur. Bu çalışmada Ocak, Nisan ve Temmuz aylarında hasat edilen yaprakların metabolik enerji içeriği Karabulut ve ark. (2006), Kamalak ve ark. (2005) bildirdiği değerlerle uyum içerisindedir. Ekim ayında elde edilen yaprakların ME içerikleri ise Karabulut ve ark. (2006) ve Kamalak ve ark. (2005) bildirdiği değerden düşük bulunmuştur. Ekim ayında hasat edilen yapraklarının ME içeriklerinin düşük olmasının sebebi, sindirim derecesinde olduğu gibi, $\mathrm{NDF}, \mathrm{ADF}$ ve kül içeriğinin bu dönemde oldukça yüksek olmasından kaynaklanmıştır. El-Shatnawi ve Mohawesh (2000), laktasyondaki koyunların yaşama payı için protein ihtiyacını rasyonda \% 7-9 ve laktasyon dönemi için ise $\%$ 10-12 ham protein olarak bildirmişlerdir. Bu yüzden Ocak ayında elde edilen yaprakların protein içeriğinin, belirli bir düzeyde de olsa koyunların yaşama payı protein ihtiyacını karşılayacak düzeyde olduğu fakat süt verimi için yeterli olmadığ düşünülmektedir. Diğer taraftan, \%5'den fazla kondense tanen içeren rasyonların besin madde sindirimini ve yem tüketimini azalttığ 1 , kondense tanenin proteinlerle bileşik oluşturarak mikroorganizmaların ve enzimlerin faaliyetini engellediği birçok araştırıcı tarafından bildirilmektedir (Singleton 1981, Lohan ve ark. 1983, Barry ve Duncan 1984, Makkar ve ark, 1989, Silanikove ve ark 1994).

Ocak ayı dışındaki dönemlerde elde edilen yaprakların hem protein içeriklerinin koyunların yaşama payı ihtiyacını karşılamaktan uzak, hem de yüksek oranda kondense tanen içermesi mevcut proteinin kullanımını oldukça düşürmesine neden olacağı düşünülmektedir. $\mathrm{Bu}$ yüzden Ocak ayı dışındaki aylarda elde edilen yaprakların hayvanlara verilirken ek protein yemine ihtiyaç olduğu gözükmektedir. Ayrıca yüksek oranda kondense tanen içermesinden dolayı, kondense tanenin negatif etkisini gidermek için rasyona, ekonomik olursa polyethylene glycol (PEG) gibi katkı maddesi katılması gerekmektedir. Aksi takdirde kondense tanen ek protein yeminin kullanımını kısitlayabilir.

Hücre duvarını oluşturan önemli bileşkeler olan NDF veya $\mathrm{ADF}$ içeriği ile IVKMSD arasındaki ilişki Şekil 1 ve 2' de verilmiştir. Görüldüğü gibi sandal ağacı yaprağının $\mathrm{NDF}$ ve ADF içeriklerinin artmasıyla birlikte IVKMSD'de önemli düşüşler meydana gelmiştir.

$\mathrm{Bu}$ çalışmada elde edilen bulgular Kamalak ve ark. (2004b) belirtmiş oldukları değerler ile paralellik göstermiştir. Yaprakların NDF ve ADF içerikleri ile ME arasındaki ilişki ise Şekil 3 ve 4'de verilmiştir. Sandal ağacı yaprağının NDF ve ADF artmasıyla birlikte ME değerinde önemli düşüşler meydana gelmiştir. Bu çalışmada elde edilen bulgular Kamalak (2006) değerleri ile benzer bulunmuştur. Sandal ağacının makro ve mikro mineral madde 
kompozisyonuna hasat zamanına etkisi Çizelge 2'de verilmiştir. Genel olarak bakıldığında hasat zamanı sandal ağacı yaprağının makro mineral içeriğini önemli derecede etkilemiştir.

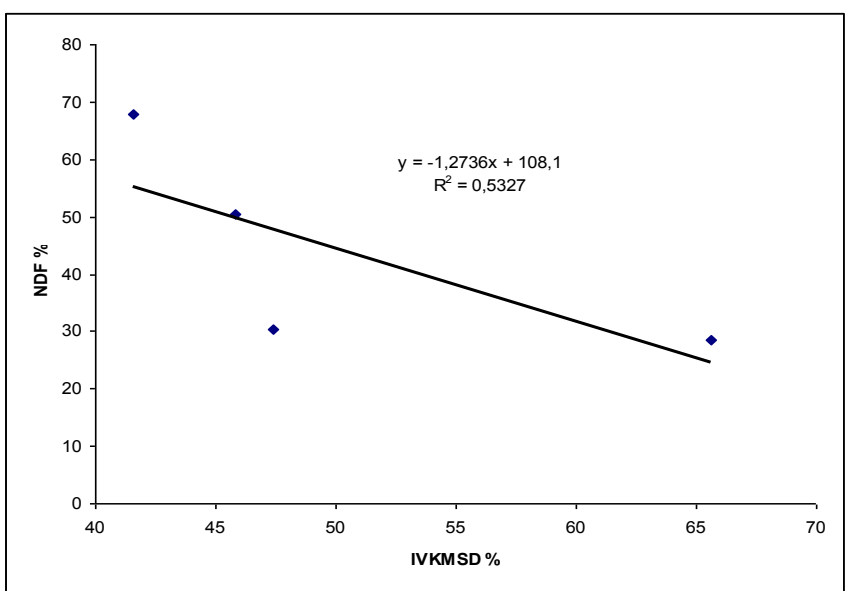

Şekil 1. NDF içeriği ile IVKMSD arasındaki ilişki

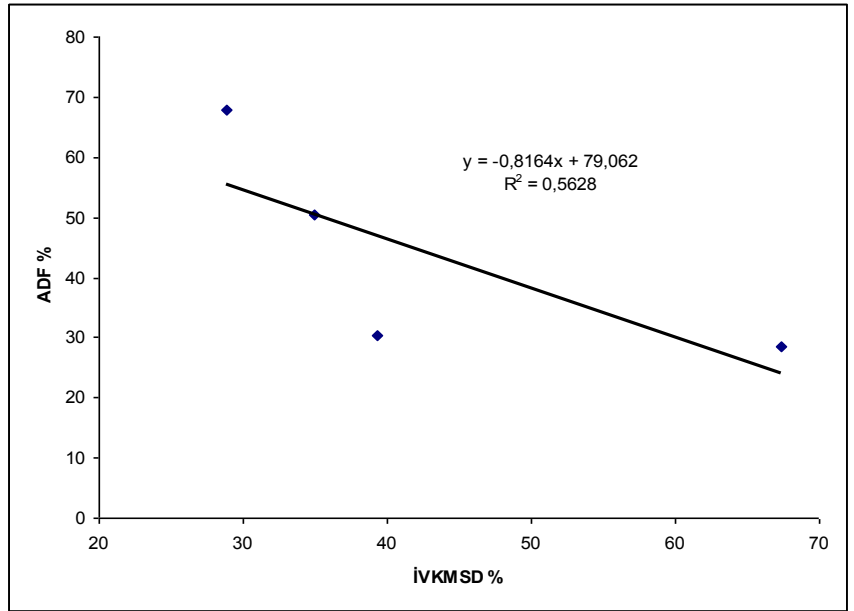

Şekil 2. ADF içeriği ile İVKMSD arasındaki ilişki

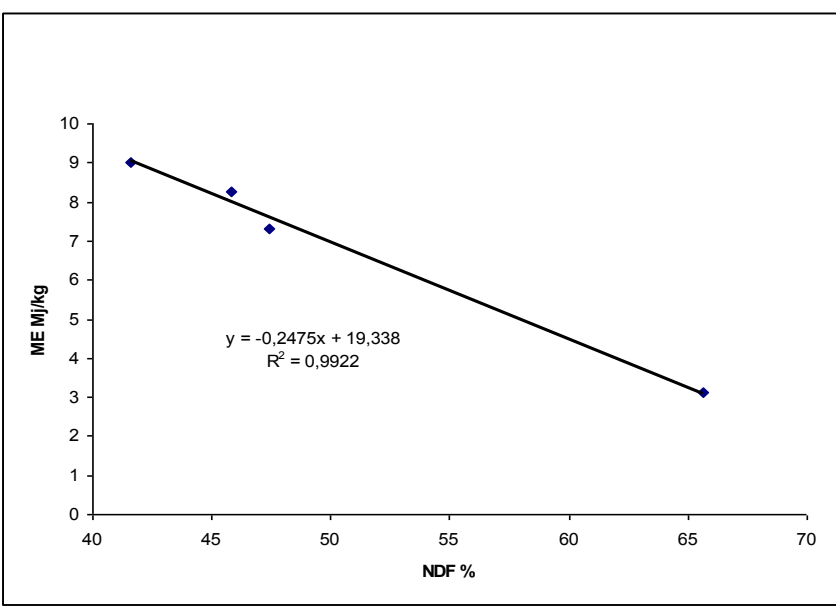

Şekil 3. NDF içeriği ile ME arasındaki ilişki

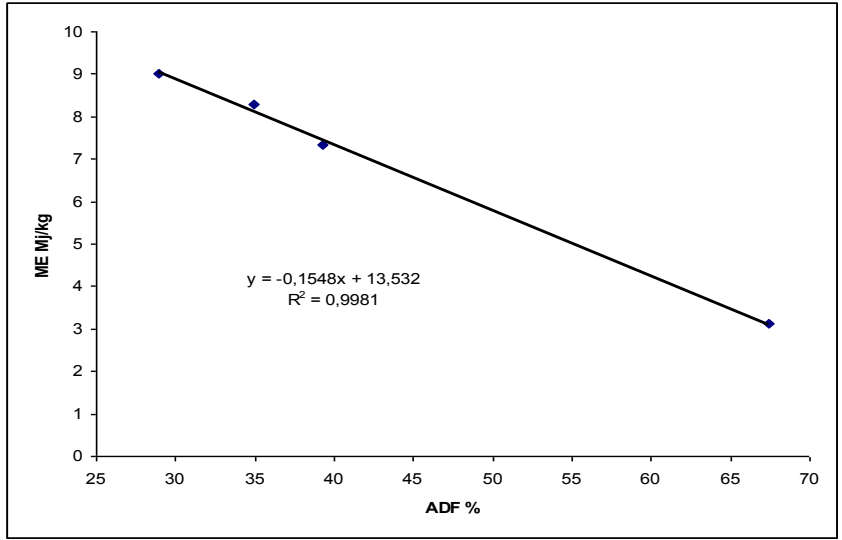

Şekil 4. ADF içeriği ile ME arasındaki ilişki

Ca içeriği \%1.11 ile \% 1.59 arasında değişmiş ve en yüksek Ocak ayında en düşük ise Ekim ayında toplanan yapraklarda bulunmuştur. $\mathrm{Ca}$ içeriği mevsimin ilerlemesi ile azalmıştır. Yapraklardaki P içeriği ise $\% \quad 0.07$ ile $\% \quad 0.12$ değerleri arasında bulunmuş olup, Ca içeriğinde olduğu gibi en yüksek fosfor içeriği de Nisan ayında ve en düşük ise Ekim ayında hasat edilen yapraklarda saptanmıştır Yaprakların $\mathrm{Mg}$ ve $\mathrm{K}$ içerikleri de mevsimlere göre değişiklik göstermiştir.

Hasat zamanı makro mineral içeriklerinde olduğu gibi mikro mineral içeriğini de önemli derecede etkilemiştir. Sandal ağacı yaprağının Zn içeriği 21.79 ile $31.25 \mathrm{mg} / \mathrm{kg}$ kuru madde arasında değişmiştir. En yüksek Zn içeriği Temmuz, en düşük Zn içeriği ise Ocak ayında hasat edilen yapraklarda bulunmuştur. Fe içeriği ise 259.69 ile $764.94 \mathrm{mg} / \mathrm{kg}$ kuru madde arasında değişmiş olup en yüksek Fe içeriği Ocak ayında en düşük Fe içeriği Temmuz ayında hasat edilen yapraklarda bulunmuştur. Sandal yapraklarında $\mathrm{Cu}$ ise tespit edilecek düzeyde bulunmamıştır. Bütün hasat zamanlarındaki sandal ağacının Ca ve Mg içeriği NRC (1985)'nin koyunlar için bildirdiği değerden (Ca: \% 0.20-0.80; Mg: \% 0.12-0.18) yüksek bulunmuştur. Bütün hasat zamanlarındaki sandal ağacının fosfor içeriği ise NRC (1985)'nin koyunlar için bildirdiği değerden (P: \% $0.16-0.38$ ) düşük bulunmuştur. Diğer taraftan Ekim ayında hasat edilen sandal ağacının K içeriği NRC (1985)'nin bildirdiği değerden (K: \% $0.50-0.80)$ düşük bulunmuştur, Zn içeriği ise bütün hasat dönemlerinde benzer (Zn: 20-33 mg/kg) bulunmuştur. Ocakta hasat edilen sandal ağacının Mn içeriğ̀i NRC (1985)'nin bildirdiği değere (Mn: 20-40 mg/kg) yakın olmasına rağmen, diğer dönemlerde hasat edilen sandal ağacı yapraklarının Mn içeriği NRC (1985)'nin bildirdiği değerden daha düşük bulunmuştur.

Diğer taraftan bütün dönemlerde hasat edilen yapraklardaki demir ise, NRC (1985)'nin bildirdiği değerden (Fe:30-50 mg/kg) çok yüksek bulunmuştur. Dört farklı zamanda hasat edilen sandal yapraklarında $\mathrm{Cu}$ elementi tespit edilememiştir. 
Çizelge 2. Sandal ağacının makro ve mikro mineral madde kompozisyonuna hasat zamanına etkisi

\begin{tabular}{|l|c|c|c|c|c|c|}
\hline Mineral & \multicolumn{5}{|c|}{ Dönemler } & \\
\hline Makro elementler (\%) & Ocak & Nisan & Temmuz & Ekim & SHO & ÖS \\
\hline Ca & $1.59^{\mathrm{a}}$ & $1.49^{\mathrm{ab}}$ & $1.37^{\mathrm{b}}$ & $1.11^{\mathrm{c}}$ & 0.042 & $* * *$ \\
\hline $\mathrm{P}$ & $0.09^{\mathrm{b}}$ & $0.12^{\mathrm{a}}$ & $0.08^{\mathrm{c}}$ & $0.07^{\mathrm{d}}$ & 0.002 & $* * *$ \\
\hline $\mathrm{Mg}$ & $0.24^{\mathrm{c}}$ & $0.22^{\mathrm{d}}$ & $0.37^{\mathrm{a}}$ & $0.30^{\mathrm{b}}$ & 0.034 & $* * *$ \\
\hline $\mathrm{K}$ & $0.64^{\mathrm{a}}$ & $0.55^{\mathrm{b}}$ & $0.60^{\mathrm{bc}}$ & $0.44^{\mathrm{c}}$ & 0.0152 & $* * *$ \\
\hline Mikro elementler (mg/kg KM) & & & & & & \\
\hline $\mathrm{Zn}$ & $21.79^{\mathrm{b}}$ & $29.94^{\mathrm{a}}$ & $31.25^{\mathrm{a}}$ & $23.89^{\mathrm{b}}$ & 0.92 & $* * *$ \\
\hline $\mathrm{Fe}$ & $764.97^{\mathrm{a}}$ & $608.72^{\mathrm{ab}}$ & $259.69^{\mathrm{c}}$ & $517.40^{\mathrm{b}}$ & 43.65 & $* * *$ \\
\hline $\mathrm{Mn}$ & $25.02^{\mathrm{a}}$ & $16.78^{\mathrm{b}}$ & $13.25^{\mathrm{c}}$ & $13.12^{\mathrm{c}}$ & 3.70 & ÖD \\
\hline $\mathrm{Cu}$ & $\mathrm{TE}$ & $\mathrm{TE}$ & $\mathrm{TE}$ & TE & TE & TE \\
\hline
\end{tabular}

abc Aynı üst simgeye sahip ve aynı satırda yer alan ortalamalar arasında fark yoktur (P>0.05), SHO: Standart hata ortalaması, ÖS: Önem seviyesi, TE: Tespit edilemedi.

\section{SONUC}

Sandal ağacı yapraklarının kompozisyonu, İKMSD ve ME içeriği hasat zamanına bağlı olarak önemli derecede değişmiştir. Yaprakların ham protein içeriği bir kısım ihtiyaçları karşılamasına rağmen, bütün dönemlerde koyun ve keçilerin ihtiyacının tamamını karşlayacak düzeyde olmadiğından, hayvanlara verilen rasyonlar ek bir protein kaynağı ile desteklenmelidir. Özellikle gebelik dönemi ve gebeliğin son $1.5^{-} 2$ aylık dönemi ile laktasyon döneminde bu ek yemleme mutlaka yapılmalıdır. Sandal ağacı yaprağı ile beslenen koyunlar bütün dönemlerde $\mathrm{P}$ ve $\mathrm{Cu}$ bakımından ek yemlemeye ihtiyaç duyarken, Mn bakımından ise Ocak ayı dışında ek yemlemeye ihtiyaç duymaktadır. Bunu sağlamak için fosfor bakımından zengin yemler verileceği gibi mineral karması da rasyona katılabilir. Bu durumda özellikle bahar aylarında pratik bir yaklaşım olarak mineral ihtiyaçlarını karşılamak amacıyla yalama taşı kullanılabilir.

\section{TEŞEKKÜR}

$\mathrm{Bu}$ çalışma, Adile Tatlıyer'e ait Yüksek Lisans tez çalışması olup, KSU Bilimsel Araştırmalar Merkezi tarafından desteklenmiştir (Proje No: 2010 / 5-3 YLS).

\section{KAYNAKÇA}

Ammar H, L'opez S, Gonz'alez JS 2005. Assessment of the digestibility of some Mediterranean shrubs by in vitro techniques. Small Ruminant Research, 119:323-331.

AOAC., 1990. Official method of analysis. 15th ed., pp.66-88. Association of Official Analytical Chemists, Washington, DC, USA.

Baldwin IT, Schults JC, Ward D 1987. Patterns and sources of leaf tannin variation in yellow birch (Betula allegheniensis) and sugar maple (Acer saccharum). Journal of Chemical Ecology, 13:106978.

Barry TN, Duncan SJ 1984. The role of condensed tannins in the nutritional-value of Lotus pedunculatus for sheep .1. Voluntary intake. British Journal of Nutrition, 51: 485 - 491.,

Degen AA, Blanke A, Becker K, Kam M, Benjamin RW, Makkar HPS 1997. The nutritive value of Acacia saligna and Acacia salicina for goats and sheep. Animal Science, 64(2):253-9.

El-Shatnawi MK, Mohawesh YM 2000. Seasonal chemical composition of saltbush in semiarid grassland of Jordan. Journal of Range Management, 53:211-214

Getachew G, Makkar HPS, Becker K 2000. Effect of polyethylene glycol on in vitro degradability of nitrogen and microbial protein synthesis from tannin-rich browse and herbaceous legumes. British Journal of Nutrition, 84: 73-83.

Hagerman AE 1988. Extraction of tannin from fresh and preserved leaves .Journal of chemical Ecology, 14(2): 453-61.

Jones JB, Benton J, Case VW 1990. Sampling, handling and analyzing plant tissue samples. Sampling, handling and analyzing plant tissue samples., (Ed. 3), 389-427.

Kamalak A, Canbolat O, Gurbuz Y 2004a. Comparison between in situ dry matter degradation and in vitro gas production of tannin-containing leaves from four tree species. South African Journal of Animal Science, 34(4): 233-240.

Kamalak A, Filho JMP, Canpolat O, Gurbuz Y, Ozay O, Ozkan CO 2004b. Chemical composition and its relationship to in vitro dry matter digestibility of several tannin-containing trees and shrub leaves. Livestock Res Rural Dev, 16: 1-8.

Kamalak A, Canbolat O, Gurbuz Y, Ozay O, Ozkose E 2005. Chemical composition and its relationship to in vitro gas production of several tannin containing trees and shrub leaves. Asian-Australasian Journal of Animal Science, 18(2):203-208.

Kamalak A 2006. Determination of nutritive value of leaves of a native grown shrub, Glycyrrhiza glabra L. using in vitro and in situ measurements. Small Ruminant Research, 64: 268-278. 
Kamalak A, Canbolat O, Atalay AI, Kaplan M 2010. Determination of potential nutritive value of young, old and senescent leaves of Arbutus andrachne tree. Journal of Applied Animal Research, 37(2): 257260.

Karabulut A, Canbolat O, Ozkan CO, Kamalak A 2006. Potential nutritive value of some Mediterranean shrub and tree leaves as emergency food for sheep in winter. Livestock Research for Rural Development, 18(6): 81.

Kumar R, Vaithiyanathan S 1990. Occurrence, nutritional significance and effect on animal productivity of tannins in tree leaves. Animal Feed Science and Technology, 30: 21-38.

Kuo S 1996. Phosphorus. In D.L. Sparks (ed) Methods of soil analysis: Chemical methods. Part 3. SSSA, Madison, WI, 869-921.

Lohan OP, Lall D, Vaid J and Negi SS 1983. Utilization of oak tree fodder in cattle ration and fate of oak leaf tannins in the ruminant system. Indian Journal of Animal Science, 53: 1057-1063.

MAFF 1984. Energy allowances and feeding systems for ruminants. Reference Book 433, Ministry of Agriculture, Fisheries and Food, London.

Makkar HPS, Singh B and Negi SS 1989. Relationship of rumen degradability with microbial colonization, cell wall constituents and tannin levels in some tree leaves. Animal Production, 49: 299-303.

Makkar HPS, Dawra RK, Singh B 1991. Tannin levels in leaves some oak species at different stages of maturity. Journal of the Science of Food and Agriculture, 54:513-9.

Minoletti ML, Boerner REJ 1994. Drought and site fertility effects on foliar nitrogen and phosphorus dynamics and nutrient resorption by the forest undershrub Viburnum acerifolium Latin American Midland Naturalist 131: 109-119.

Norton BW 2003. The nutritive value of tree legumes. http://www.fao.org/ag/AGP/AGPC/doc/Publicat/Gut $\mathrm{t}$-shel/x5556e0j.htm. pp.1-10

NRC 1985 Nutrient requirements of Sheep. Sixth Revised Edition. National Academy Press. Washington D.C.
Silanikove N, Gilboa N, Nir I, Perevolotsky Z, Nitsan Z 1996. Effect of a daily supplementation of polyethylene glycol on intake and digestion of tannin-containing leaves (Quercus calliprinos, Pistica lentiscus, Ceratonia siliqua) by goats. Journal of Agriculture and Food Chemistry, 44:199205

Silanikove N, Prevolotsky A, Provenza FD 2001. Use of tannin-binding chemicals to assay for tannin and their negative effects in ruminants. Animal Feed Science and Technology, 9(1-2), 69-81.

Silanikove N, Nitsan Z, Perevolotsky A 1994. Effect of a daily supplementation of poly (ethylene glycol) on intake and digestion of tannin-containing leaves (Ceratonia siliqua) by sheep. Journal of Agricultural and Food Chemistry, 42(12): 28442847.

Smith, O. B., 1992. Fodder trees and shrubs in range and farming systems in tropical humid Africa. Legume trees and other fodder trees as protein sources for livestock.(Eds. A. Speedy and PL Pugliese). FAO. Animal Production and Health Paper, 102, 43.

Singleton VL 1981. Naturally occurring food toxicants: Phenolic substances of plant origin common in foods. Advances in Food Research, 27:149-242.

Tilley JMA, Terry RA 1963. A two stage technique for the in vitro digestion of forage crops. Journal of British Grasslands Society, 18:104-111.

Tolera A, Khazaal K, Orskov ER 1997. Nutritive evaluation of some browses species. Animal Feed Science and Technology, 67: 181-195.

Van Soest PV, Robertson, JB, Lewis BA 1991. Methods for dietary fiber, neutral detergent fiber, and nonstarch polysaccharides in relation to animal nutrition. Journal of dairy science, 74(10): 35833597.

Yamamura Y 1986. Matter-economical roles of the evergreen foliage of Aucubajaponica, an understory shrub in warm-temperate region of Japan. 1. Leaf demography, productivity and dry matter economy. The Botanical Magazine Tokyo. 99: 323-332. 